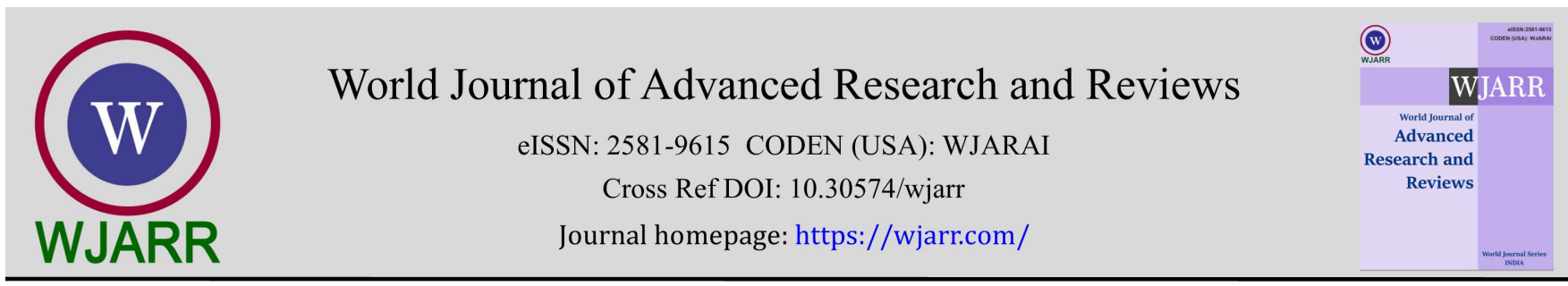

(REVIEW ARTICLE)

Check for updates

\title{
Influence of social entrepreneurs on community development in Enugu west senatorial district of Enugu state, Nigeria
}

Nweke Prince Onyemaechi ${ }^{1}$, Micheal Temitope Elesho ${ }^{2,}{ }^{*}$, Imo Onyeodiri Charity ${ }^{3}$, Matthias U Agboeze ${ }^{3}$, Igwe Ngozi Justina $^{3}$, Eze Georgina Chinagorom ${ }^{3}$, Okengwu Mary Chinyere ${ }^{3}$ and Nwankwo Benedict Chimezie ${ }^{4}$

${ }^{1}$ Institute of Education, University of Nigeria, Nsukka.

2 Department of Public Administration, Faculty of Social Sciences, University of Nigeria, Nsukka.

${ }^{3}$ Department of Adult Education and Extra-Mural Studies, Faculty of Education, University of Nigeria, Nsukka.

${ }^{4}$ Department of Psychology, Faculty of Social Sciences and Humanities, Ebonyi State University, Abakaliki.

World Journal of Advanced Research and Reviews, 2021, 11(01), 001-007

Publication history: Received on 26 May 2021; revised on 29 June 2021; accepted on 01 July 2021

Article DOI: https://doi.org/10.30574/wjarr.2021.11.1.0304

\begin{abstract}
Social entrepreneurship is not a new-fangled observable fact in Nigeria. Though the practice has constantly existed, for countless reasons, the concept is gaining reputation in current years. Although the focus has been on business entrepreneurship as a tool for economic development, the light is now on social entrepreneurship, which entails attempting to serious social issues for sustainable community development. Community development efforts have met with diverse challenges that hamper sustainability of the society. The appearance of social entrepreneurship as a cross move towards positive force for transforming communities put forwards the prospects of dealing with the key challenges of lack of support by government, deficiency of financial assistant, changing environment, out of pocket work, domination by wealthy founders and philanthropists, lack of skilled manpower, poverty, unemployment, illiteracy, climate changes, health care challenges, insecurity and other social and economic issues. This paper throws light on who social entrepreneurs are what they do and the role they play in achieving sustainable community development. Using a conceptual framework defined social entrepreneurs, characteristics, principles and role of social entrepreneurs towards community development process. The paper concludes with suggestive principles that could provide an enhanced insight on the role of social entrepreneurs in community development. To enhance their impact, social entrepreneurs should involve beneficiaries trapped within socio-economic problems in the process of community development.
\end{abstract}

Keywords: Social entrepreneurship; Social change; Community; Development; Community development

\section{Introduction}

There is negative deliberation as to whether social entrepreneurs have a responsibility to participate in the development of whichever economy. The root seems to be to what extent they append value to society. Social entrepreneurship has emerged as a modern matter in the social ground. It is a concept healthy suited for this age (Dees, 2001). The author further postulated that there is need for entrepreneurial activities to spearhead the resolving of social issues; since many governmental and charitable efforts have failed to meet the existing social needs. Dees therefore makes a case for social entrepreneurs by highlighting that they fill the gap that has been left void by the ineffectiveness, inefficiency and the lack of sustainability from major institutions. While it may seem as though Dees has attached some nobility to the concept, Mair and Mati (2006) are also of the opinion that the concept catalyzes social change and addresses important social needs in a way that is not dominated by direct financial benefit for an entrepreneur. According to the authors, this is because social entrepreneurship is seen as differing from other forms of

\footnotetext{
* Corresponding author: Micheal Temitope Elesho

Department of Public Administration, Faculty of Social Sciences, University of Nigeria, Nsukka.
} 
entrepreneurship in the relatively higher priority given to promoting social value and development versus capturing economic value. Interesting, Portia, Chux and Victor (2014), posited that social entrepreneurship signifies a business model for individuals and non-governmental organizations fulfilling on social issues in the society at large.

\section{Conceptual framework}

Social entrepreneurship has been described as one of the defining trends of the 21st century (Mair 2010). In the past two decades, it has become a stylish phenomenon often shown by success stories across the world in diverse fields such as education, health, culture and so on (Light, 2010). According to Dees (2001), the notion of social entrepreneurship is well suited to this era. Furthermore, the author points out the importance of the innovative actions of social entrepreneurs, which lead to the resolution of social problems, while government and the charitable efforts of traditional organizations are falling short in alleviating the current social challenges. Entrepreneurial activity is the process by which the efforts of individuals are united with those of certain types of organizations to solve socioeconomic problems of disadvantaged areas (Mair \& Marti, 2006; Urban, 2008). The European Commission (2013) describes social entrepreneurship as an approach to make impact on society and economy. The social entrepreneurship paradigm can help local communities to realize their unmet needs and improve the lives of the people through innovative ways. Social entrepreneurship is therefore a significant tool in addressing social problems including unemployment, poverty, and education (Smith \& Stevens, 2008).

Social entrepreneurship therefore, refers to the identification of a social problem and the utilization of entrepreneurial principles to systematize creates and controls a social enterprise to achieve a desired social change. Moreso, it engages the ability to see 'problems' as 'opportunities' and then take the initiative to make out the solutions to those problems and the customers who could pay to have them solved. Importantly, social entrepreneurship fosters wealth for society as a whole, contributes to community development projects, supports environmental sustainability and produces social capital. On the other hand, social entrepreneurs hunt for serve the attention of the community by creating solutions that tackle community needs and by engaging in sustainable livelihoods that benefit them and their communities at large. Therefore, prearranging this perceptive, it is kindly to state that by pursuing innovation solutions to social problems, one is said to engage in the process of social entrepreneurship. While social entrepreneurship can be seen as a process which includes recognition of a particular social problem and a solution to address it, the evaluation of the social impact realized the sustainable model of the business that addresses the social and environmental or community problems.

Rural communities in Nigeria are overwhelmed with myriads of brave that impede growth and development. Unemployment and poverty are among the key challenge's communities are faced with (Ngatse-Ipangui \& Dassah, 2019). Achieving community development has been arduous despite the various strategies adopted by government, local agencies and Non-Governmental Organizations (NGOs). However, the high levels of unemployment, poverty and the consequent effects they create inhibit social and economic development. Given this situation, there is an urgent need for the design and implementation of innovative projects that can provide sustainable, long-term solutions to social problems. Community development is therefore, concerned with improvement in the quality of life and standard of living of a community. According to Ekong (2010), Nigeria is predominantly rural with over 60 per cent of people living in rural communities. For this reason, community development efforts ought to be geared towards improvement in the standard of living of the people and making the process of their development self-sustaining. This understanding, informed the community development efforts of successive governments in Nigeria targeted in the rural communities. Regrettably, most of the community development efforts have failed to yield the desired results despite various strategies and efforts. This situation as argued by Udu and Onwe (2016) has continued to result in a situation where there is visible mismatch between the community structure and the kind of empowerment programmes targeted at them. Importantly, a promising approach to community development that complements development assistance is social entrepreneurship. It is believed that social entrepreneurial initiatives have the potential to provide sustainable, long-term solutions to community development. However, the concept is one that could be considered as its practice could contribute positively to community development in the areas of impact and sustainability.

\section{Characteristics of social entrepreneurs}

The common factor found in social entrepreneurs is their focus on making change through their actions, which may lead to solutions to society problems. Social entrepreneurs are individuals with new concept to tackle main issues that are determined in the pursuance of their perceptions, people who simply could not terminate until their ideas are spread to the extent they can (Bornstein, 2007). The following key attributes characterize social entrepreneurs (Martin and Osberg, 2007): Social entrepreneurs have a high initiative and are reformers with a social aim, tackling major social obstacle and offering raw concepts and wide - ranging clarifications; Searching and identifying what other social issues are missing, they take advantage of these opportunities for improving current social systems, creating solutions and 
inventing new methods that create satisfactory social values; Social entrepreneurs do not function in the business world in a social framework. As a result of their limited access to capital requirements, they have skills and mobilize all necessary resources for solving social problems; Successful social entrepreneurs have the extreme goal not only of building wealth, but also of developing as much social value as possible; and social entrepreneurs are ultimately driven to achieve significant outcomes that adjust current situations for the benefit of society as a whole.

Social entrepreneurs are ultimately driven to achieve significant outcomes that adjust current situations for the benefit of society as a whole. According to Martin and Osberg (2007), Three basic components of social entrepreneurship are: Identifying a stable but unjust balance that prevent, criticizes or damage a group that does not have the instrument to improve balance; recognizing opportunity chance and expanding a newly proposed social value to claim balance; and finally, the suffering by creating a durable ecosystem was alleviated by the development of a new stable balance to provide a better future.

\section{Principles of social entrepreneurship}

Social entrepreneurship according to Ihejiamaizu and Udensi (2017) can be characterized by the adoption and practice of several principles. These principles help to define the purpose of a social enterprise. Interestingly, Chia and Wei (2016) identified three guiding principles. First, social entrepreneurs apply business and management principles to solving social problems, especially where governments or markets have failed or where there are unmet needs. Second, social entrepreneurs emphasize the development of efficient, affordable and cost-effective solutions. The third guiding principle of social entrepreneurship is sustainability of solutions. Social ventures need to sustain their own existence. Research Gomez (2016) outlined guiding principles based on the study of 10 real world social enterprises.

\subsection{Cause-Driven}

Social enterprises are businesses that are cause-driven in the sense that they are created to overcome a global or local issue or challenge. Without the sole purpose of maximizing profit, social enterprises are driven by the cause they set out to pursue, that is, the objective to overcome or alleviate a global or local issue such as poverty, education, health, technology access or the environment.

\subsection{Financial and economic sustainability}

As with any other business, social entrepreneurs apply business principles to solving social problems. Thus, financial numbers and cash flow must be in line with what is expected and sustainable in the long-term.

\subsection{Investor returns}

Investors could receive a return on their investment amount only no dividend. Investors must only receive back what they put in.

\subsection{Profit generated stays in the company}

One unique attribute of a social entrepreneur is the ability to plough back profit made into the business/organization for expansion and improvement.

\subsection{Gender sensitive and environmentally conscious}

Tackling gender discrimination and inclusion is vital as well as integrating environmental impact actions.

\subsection{Workforce could receive market wage and better working conditions}

More emphasis on well-being at the workplace is given, fostering long-term relationships with employees and striving for their happiness.

\subsection{Joy in their work}

Businesses that work for a purpose of helping a cause do it with joy.

Importantly, for social entrepreneurship to be impactful in the context of community development, the following principles, as put together by Teo (2013), are essential: understand the community you want to help the needs, aspirations, dreams and motivations of members of community; understand the priority, not just needs, of community members. Community members have many needs, but they have priorities. Based on an identified priority, social 
entrepreneurs can have a scope of the specific social problem to address (Nora, 2011); beyond needs-based community development, practice asset-based community development. Mathie \& Cunningham (2003) are proponents of assetbased community development as a strategy for community-driven development. According to them, needs-based community development does not encourage community to be self-reliant; it causes community members to see themselves as deficient and incapable of taking charge of their lives and community. However, asset-based community development identifies and mobilizes community members' assets, and creates opportunities. It recognizes that community members' capacities and their associations can be harnessed to build a formidable community; obtain buyin (or support) from community members for planned intervention program. It ensures wholehearted participation in intervention program by community members; Obtain buy-in (or support) from stakeholders (e.g., government, businesses, non- profits) for planned intervention program. This principle involves identifying potential resource partners, \& establishing collaborations with them. It ensures contribution of resources by stakeholders to support intervention programmes; and to create conditions necessary for community members to empower themselves and to live with dignity. The author further posited that irrespective of the quality and guiding principles for effective community development, there are still basic challenges that affect the social entrepreneurs towards effective implement of rural projects.

\section{Challenges for Social Entrepreneurs toward Effective Community Development}

Research by Seema (2016) postulated challenges for social entrepreneurs toward effective community development, these include:

\subsection{Lack of support by government}

The majority of social entrepreneurs yet to recognize themselves as a legitimate field of endeavor. This recognition is the sine qua non for finding ways to call attention through fiscal and legislative incentives, in addition to the review of tax laws, the reducing over burden of regulations, arbitrary decision-making and other troublesome requirements and inefficient practices those creel social entrepreneurs.

\subsection{Deficiency of financial assistant}

From a financial perspective, approaching the fresh market social entrepreneurs require funding for designing, implementing and refining innovative ways of bringing previously excluded groups into the marketplace. The best and brightest talent demand for a handsome salary and stock options as a reward of their hard work.

\subsection{Changing environment}

Hence, inasmuch as the government policies are changing with changing global prospective. There is the possibility that, organizations need to be better equipped to respond to the challenges of the 21 st century.

\subsection{Out of pocket work}

The solution to various societal problems and welfare of the society carries a cost, which is mostly borne by the owner out of their own pocket or by taking loans from money lenders. Social entrepreneurs are not, as a matter of course, working in a moneymaking market; they identify a problem within society and try to find cost effective solutions for them. Once they find the way to earn some profit after providing the best low-cost solution to the needs of the society, more traditional businesses will enter the market competing with a similar solution and technique, increasing transaction costs and competition for social entrepreneurs and hampering their future growth.

\subsection{Domination by wealthy founders and philanthropists}

The challenge for social entrepreneurs relates to foundations and philanthropists who could be the ones catalyzing social transformation by supporting the social innovators. Foundations and high net worth individuals are certainly well placed to engage in that process, as they are free of two forces that dominate the decisions of governments and business respectively.

\subsection{Lack of Skilled Manpower}

Social enterprises feel necessity for competent workforce volunteers, labourers and community participants to make parallel the long-term growth motives. But social enterprises need training and development programme as they are typically employ from the underprivileged sector of the society. The organizations have to attempt to fulfil the aspirations of all these divergent groups and still come out with the best results. 


\section{Role of social entrepreneurship in community development}

Apparently, the need to do something is to improve community life, normally implies aspects of development. Community refers to a group of people living in a specific geographical locality. 'Community development' is viewed as an embracing concept concerning the improvement of the standard of living or quality of life within a community (Thomas, 2004). Regardless of the incredible efforts of public sectors and private sectors to meet the increasing gap between community needs and the performance, they have failed to meet the goal due to various limitations. Governments or non-profits are in deficits of resources due to economic limitation and weak political could. Similarly, the private sector is failing in its claim of serving all members of society due to high concentration in profit maximizing. This tendency has resulted in increasing problems in communities. However, according to Ihejiamaizu \& Udensi (2017) to overcome both the private and public sector limitations, the hybrid approach of social entrepreneurship is currently emerging as a feasible alternative to community development.

Community development work is always confronted with a lack of resources. As Lombard and Strydom (2011) posited; in the true spirit of social entrepreneurship, social entrepreneurs are change agents who could associate with efforts to combine resources so as to exploit opportunities in search of new anti-poverty interventions that could impact on social and economic development. An example of a social entrepreneur in Nigeria is Ikegwuonu (2020), who has developed a sustainable community-owned and managed radio through which farmers can share knowledge with each other. Till date, Ikegwuonu's new radio program engages listeners and tackles the important problem of declining agricultural productivity. Targeting small holder farmers, he empowers them by giving them a voice and ownership in the project, validating their indigenous knowledge, and providing fast access to markets and thus eliminating middle men. The author also disseminates important environmental information, highlighting the importance of protecting nature and its close link to agricultural productivity. The author does all this through Rural Farmers' Listening clubs. In order to ensure sustainability, the community radios charge a small fee for community announcements such as births and obituaries, and use solar power to reduce operational costs and dependence on the unreliable national power grid. The radio is directed and managed by a board comprised of the community stakeholders (Ihejiamaizu \& Udensi, 2017).

From the above example, it is clear that social entrepreneurs can play a key role in community development. A research study by Thomas (2004) using three case studies in Africa showed the contribution of social entrepreneurs in various areas of need having resulted in transformed opinions, attitudes and even policies related to the social issues that are being addressed. The factors that stand out as contributing to the impact and success of social entrepreneurship may be identified as: innovation, the social entrepreneurial champions' themselves, and the use of 'first-hand experience' in the ongoing struggle to change perceptions, traditions, attitudes and behaviors. The relevance of social entrepreneurship cannot be overemphasized since the society is still bedevilled with a lot of problems government alone cannot solve. Social entrepreneurs seek to serve the community's interest by creating solutions that address societal needs and by engaging in sustainable livelihoods that benefit themselves and their communities. In this light, Obiekezie and Ihejiamaizu (2014) maintains that the society needs individuals and groups who are sufficiently creative and innovative to put in place measures and strategies to identify and meet needs or fill gaps that are of social concern.

Importantly, in a studied carried out by Dawn (2018), posited roles of social entrepreneurship in community development, social enterprises provide a significant impact on community development. These effects can be broken down as follows: social enterprises offer a community with a sense of purpose. These enterprises tap most locals as a way to both provide income for them and answer the call of change in their community. By engaging themselves in this kind of social action, they can bring fulfilment to their hearts. Communities feel more interconnected to their fellow residents once they immerse in social enterprising. Establishing a social business like this requires a considerable number of people. Hence, collaboration is needed to be able to sustain the social enterprise in their rural communities. Social enterprises are also considered as a tool to develop the locals' skill sets. This business covers a lot of areas finance, problem-solving, creativity, technical work, risk management, and more. They are faced in a challenging environment. The learning's they get from here could then be used to further community development initiatives. Establishing social enterprises also opens the eyes of communities to the realities of the world. Familiarizing themselves with these issues inspires them to take action into the improvement of their respective communities.

\section{Conclusion}

Conclusively, social entrepreneurs have an indispensable responsibility to carry out in the revolution of the society at large. Social entrepreneurship point outs advanced and financially maintainable activities directed at social difficulties. Social entrepreneurs perform as the means of transformation for society, taking advantage of opportunities that is lacked by others for improving the scheme, discovering new methods and generating enhanced solutions to transform the society. To support social enterprise, is mirrored in the willingness to allow, care and encourage entrepreneurship 
by providing all needed capitals, it is also a significant problem in the improvement of social entrepreneurship. Therefore, social entrepreneurship has quickly proven itself as a self-motivated ground of practice and academic question. Therefore, the merely means to be sustainable is when individuals develop into entrepreneurial and are able to make profit in their daily processes to be used in achieving their community objectives. With the effect of social entrepreneurship on education and economic sectors, social entrepreneurship could be a elucidation.

\section{Recommendations}

- Social entrepreneurs should involve beneficiaries trapped within socio-economic problems in the process of community development.

- Social entrepreneurs should make their programmes known to local people via various means, including doorto-door distribution of social media or through events.

- Social entrepreneurs should embrace technological, political risk as a key opportunity for global renewal, and make it a priority to spot and legitimize those who have the capacity to imagine and the ability to implement what they imagine through disciplined innovation.

- Social entrepreneurs should encourage education institutes to develop curriculum that inspire social entrepreneurship practices among their students.

\section{Compliance with ethical standards}

\section{Acknowledgments}

The researchers appreciated all the corrections suggested and recommended by the experts before field testing. This research received no precise fund from any agency in public or private sectors.

\section{Disclosure of conflict of interest}

The researchers appreciated all the corrections suggested and recommended by the experts before field testing. The authors declare that there are no competing or potential conflicts of interest.

\section{References}

[1] Bornstein D. How to change the world: Social entrepreneurs and the power of new ideas. United States of America: Oxford University Press. 2007.

[2] Chia A, Wei LY. How social enterprises can help us meet the SDGs. 2016. Available online at: <https://blogs.adb.org/blog/how-social-enterprises-can-help-us-meet-sdgs>

[3] Dawn CC. The role of social enterprises in community development. 2018. Available online at: <https://isedsolutions.org/2018/05/07/the-role-of-social-enterprises-in-community-development/>

[4] Dees JG. Meanings of 'social entrepreneurship, working paper. Stanford University: Stanford. 2001.

[5] Diab MB. Towards social entrepreneurship and sustainable development in Lebanon. Proceedings of the 13th International Conference on Business Excellence. 2019; 56-70.

[6] Ekong EE. An introduction to rural sociology. Uyo: Dove Educational Publishers. 2010.

[7] European Commission. Social economy and social entrepreneurship. Social Europe Guide. 2013; 4(2): 59-71.

[8] Gomez E. 10 Social enterprise examples and the 7 principles that guide them. 2016.

[9] Ihejiamaizu GC, Udensi LO. Social entrepreneurship: a new approach to community development in Nigeria. 2017.

[10] Ikegwuonu N. Everyone is a change maker. 2020. Available online at: https://www.opportunitiesforafricans.com/ashoka-young-changemakers-programme-2020/

[11] Light PC. The search for social entrepreneurship, International Entrepreneurship and Management Journal. 2010; 6(3): 351-355.

[12] Lombard A, Strydom R. Community development through social entrepreneurship. Social Work PractitionerResearcher. 2011; 23(3): 327-344. 
[13] Mair J, Marti I. Social entrepreneurship research: A source of explanation, prediction and delight. Journal of World Business. 2006; 41(5): 36-48.

[14] Mathie A, Cunningham G. From clients to citizens: asset-based community development as a strategy for community driven development. Development in Practice. 2003; 13(5): 474-486.

[15] Martin RL, Osberg S. Social entrepreneurship: The case for definition (Vol. 5, No. 2, pp. 28-39). Stanford, CA: Stanford social innovation review. 2007.

[16] Ngatse-Ipangui R, Dassah MO. Impact of social entrepreneurs on community development in the Cape Town Metropolitan Municipality area, South Africa. Journal for Transdisciplinary Research in Southern Africa. 2019; 15(1): 474.

[17] Nora LM. The emperor's new clothes all over again: A tale from Palestine. Development. 2011; 54(4): 514-519.

[18] Obiekezie EO, Ihejiamaizu GC. Social entrepreneurship. In Bassey U. U. Nwagbara E. N. and Bisong S. A. (Eds.). Entrepreneurship development in Nigerian Universities: A Theoretical Approach. Calabar: Sunnytech Concept Publication, Second Edition. 2014; 120-139.

[19] Portia M, Chux G, I wu, Victor VM. Social Entrepreneurs and Community Development. A Literature Analysis. Mediterranean Journal of Social Sciences. 2014; 5(16): 18 - 26.

[20] Seema D. Social entrepreneurship: challenges in way to rise. International Journal of Research - Granthaalayah. 2016; 4(9): 191-197.

[21] Smith BR, Stevens CE. Different types of social entrepreneurship: The role of geography and embeddedness on the measurement and scaling of social value. Entrepreneurship \& Regional Development. 2010; 22(6): 575-598.

[22] Teo AC. Community engagement and impactful social entrepreneurship. 2013. Available online at: http://www.rupp.edu.kh/projects/delphe/2013/2-Prof\%20Albert\%20Teo.pdf

[23] Thomas CJ. The role of social entrepreneurship in community development. An unpublished Master's Thesis of the University of the Witwatersrand, Johannesburg, South Africa. 2004.

[24] Urban B. Social entrepreneurship in South Africa skills. International Journal of Entrepreneurial Behaviour \& Research. 2008; 14(5): 346-363. 